\title{
The Involved, Engaged or Partnership Parents in Early Childhood Education and Care
}

\author{
Anders Råde \\ Department of Applied Educational Science, Faculty of Social Sciences, Umeå University, Sweden \\ Received March 2, 2020; Revised April 21, 2020; Accepted May 20, 2020
}

Copyright $(2020$ by authors, all rights reserved. Authors agree that this article remains permanently open access under the terms of the Creative Commons Attribution License 4.0 International License

\begin{abstract}
The parental relationship in ECEC (Early Childhood Education and Care) service forms a key factor for its quality. This relationship is also complex and problematic and can be understood in different ways. There is a lack of research about the parental relationship in ECEC compared with schools. However, some researches have revealed the importance of a functional parental relationship in ECEC but also that the relationship can challenge the professional task of the teachers. One way to understand the parental relationship is study it out of two different frameworks, a vertical or horizontal framework. The vertical framework regards the teachers as experts and with asymmetrical, involved or engagement parental relationship. The horizontal framework regards both teachers and parents as experts and with a symmetrical partnership parental relationship. This review of research has scrutinised how the parental relationship in ECEC is described based on a division into levels as parental involvement, engagement or partnership relation. All three levels were identified in the 22 articles studied, but with a slight domination of the parental partnership. Four advantages of the parental relationship have been identified, quality-indicator, empowerment of parents and teachers, impact on future student academic achievement and flexible relationship. Three problems have been identified, different roles of parents and teachers, discrimination and complex relationship. One conclusion is that the parental relationship is of great importance to the ECEC service, but that it is more realistic to consider this as a balance between vertically and horizontally-framed parental relationships in ECEC services.
\end{abstract}

Keywords Parents, Relationship, Partnership, Engagement, Involvement, Early Childhood Education and Care, School, Teachers

\section{Introduction}

As a result of growing pressure on children to acquire specific knowledge and skills from an early age, ECEC (Early Childhood Education and Care) services play an increasingly important role in supporting families and giving children a good start in their life-long learning, (Bennet, 2005; Chan \& Ritchie, 2016; Hujala et al., 2009; Jinnah \& Walters, 2008; Rouse \& O`Brian, 2017. Parental relationships i.e. relations between parents and the institutions, in the education of children of all ages have been regarded as important in research literature for at least 50 years (Cox, 2005; Epstein, 2018; Hornby \& Lafaele, 2011), and have also been recognised as a key factor in ECEC services since the time of Froebel in the 19th century (Pramling Samuelsson et al., 2006). There is evidence in research that the relationship between parents and ECEC exerts a positive effect on child achievement in the later school career (Arnold et al., 2008; Galindo \& Sheldon, 2012; Hujala et al., 2009; Janssen \& Vanderbroeck, 2018; Rimm-Kaufmann \& Pianta, 2001). In general, a good relationship with parents has many advantages, as it has a positive impact on teacher morale and school climate, the behaviour of children, as well as parental confidence and interest in the education of their children (Pomerantz et al., 2007). It may also be argued that a democratic ethos in ECEC implies participation of parents and professionals on more equal terms (Moss, 2007). Parents can increase the quality of an educational programme, which is especially important when it comes to children in their early years as they have closer relationship with their parents than older children (Rouse \& O`Brian, 2017).

However, the relationship with parents in ECEC is also complex and may be problematic. One reason may be the division of power between parents and professionals (Einarsdottir \& Jónsdóttir, 2017). Another reason may be that the professionals can feel de-professionalised by the increased presence of parents in ECEC (Blackmore \& Hutchison, 2010). Research on parental relationships in schools is a strong and growing field (Castelli \& Pepe, 2008; Löfdahl, 2014), however there are few studies focusing on parental relationships in ECEC services 
(Janssen \& Vandenbroeck, 2018). There seems also be a risk that the trend with more academic ECEC curriculum in some countries can reduce the influence of the parents in ECEC (Wood \& Hedges, 2016). For these reasons, the aim of this review is to scrutinise how parental relationship in ECEC are described and understood in research. The research questions are, What different levels of parental relationship in ECEC can be found in research? What advantages and problems are connected to the parental relationship in ECEC according to the research?

\section{Different Levels of Parental Relationships}

The school and ECEC services relationship with parents in education has been understood in different ways. One influential mapping was carried out by Epstein (1990) who produced a typology consisting of six types of parental involvement. Type 1 focuses on the creation of positive home environments that support children's learning, and Type 2 on various forms of communications between schools and homes. Type 3 concerns parental participation at school and Type 4 parent involvement in learning activities at home, including parent, child and teacher-initiated activities. Type 5 is about parental involvement in school decisions through participation in advisory councils, advocacy groups etc. and Type 6 about collaboration with the community. This mapping has inspired other researchers to develop their own versions of this framework for use in ECEC (Alasuutari, 2010; Goodall \& Montgomery, 2014; Hakyemez-Paul et al., 2018).

\section{Vertically and Horizontally-framed Parental Relationships}

Earlier studies on parental relationships in ECEC have revealed two different frameworks for such relationships (Alasuutari, 2010), vertical and horizontal. This use of these frames was inspired by the terminology of Bernstein (1990) and was developed by Aronsson and Evaldsson (1993) in a discourse analysis about power relations in ECEC settings.

The vertical framework, within the parental involvement and engagement levels, describes the relationship between parents and the ECEC on the basis of the expert knowledge of the professionals and the asymmetric, hierarchical relation between the two groups (Alasuutari, 2010). This framework is a more traditional approach to the parent-professional relationship (Einarsdottir \& Jónsdóttir, 2017). The horizontal framework within parental partnership describes a relationship of parallel expertise and proximity between professionals and parents (Alasuutari, 2010). In this framework, the relationship is symmetric and professionals and parents act more like partners and work together in collaboration. This framework is in accordance with recent discussions about, and approaches to, expertise and democratic professionalism in ECEC (Einarsdottir \& Jónsdóttir, 2017).

There are both positive dimensions and factors connected with the vertically-framed relationship with parents. One benefit is that in such a relationship the professionals have a more general focus on responsibility for all the children compared with the parents' more particular focus on their own child (Ivarsson Jansson, 2001), also different emotional connections, knowledge of the ECEC curriculum and power than the parents (Franklin et al., 2004). One potential problematic factor with the vertically-framed partnership is that a hierarchical and more distant type of relationship may exclude some parents. Moreover, a professional focus on literature and writing in school can exclude parents with traditions based on more visual and oral forms of communication (Souto-Manning \& Swick, 2006). Such exclusion may be connected to educational level, the social class or ethnicity of the parents and may exert a discriminatory effect. This effect may also be reinforced by professionals using the compensating model in their relationship to parents (Donzelot, 1997). Here, a rethinking of the concept of parental relationship might reduce these disadvantages, resulting in an alternative approach where professionals are more sensitive and open-minded to parents and families from different cultures or traditions (MacNaughton \& Hughes, 2011; Souto-Manning \& Swick, 2006).

There are also positive dimensions and factors connected with the horizontally-framed relationship between professionals and parents. An effective partnership can lead to important qualities such as family orientation, positivity, sensitivity, responsiveness and friendliness (McWilliam et al., 1998). A positive partnership between parents and ECEC professionals with effective two-way communication and efforts made on both sides can successfully meet the needs of the children (Chu, 2018). Such partnerships are especially important for the development of and learning by children with disabilities as it helps the successful implementation of strategies concerning interventions and support (Dunlap \& Fox, 2007; Keen, 2007; Summers et al., 2007). It may also contribute to the empowerment of the parents and boost local democracy, which in turn can result in citizens who are able to create local, collective knowledge about what is in their children's best interests (Dunst \& Dempsey, 2007; Hughes \& MacNaugthon, 2000). This might also lead to parents becoming involved in curriculum decisions (Mercedes Nalls et al., 2010).

One problematic factor with the horizontally-framed relationship with parents in ECEC is that, depending on the families' socioeconomic or cultural background, parents may possess different competences and opportunities to engage in the ECEC (Daniel, 2015; Einarsdottir \& Jónsdóttir, 2017; Hornby \& Lafaele, 2011; Markström, 2009). Parents also have a more particular interest in their own children than the professionals, who have a more general interest in all the children at the ECEC service (Ivarsson Jansson, 2001; Hughes \& MacNaugthon, 2000). Professionals may also be a hindrance to the development of serious partnership with parents if they do not really 
want, or lack the opportunity, to create a true partnership that is underpinned by mutuality, reciprocity and shared planning and decision-making (Keen, 2007; Rouse and O'Brian, 2017). Another hindrance may be professionals' anxieties as regards their relationship with parents and the challenges involved in assessing and adjusting their professional thinking to diversity among parents (Hughes \& Mac Naugthon, 2001; Mercedes Nalls, et al., 2010; Tayler, 2006). The position adopted by the professional leaders may also be crucial for the effective functioning of parent-school partnerships (Tayler, 2006). Another factor is diversity in the understanding of parental relationship among professionals and parents (Hilado et al., 2013). There are also risks that the voice and will of the child is excluded from the partnership and that the child becomes an object for the ambition of the parents and the professionals (Alasuutari \& Markström, 2011; Leiminer \& Baker, 2000). Further, the partnership model has been criticised on the grounds that when parents are given more responsibility in ECEC, they become more accountable (Franklin et al., 2004). This is a kind of post-welfarism with a reprivatisation of the responsibility for the self, the family and the child back onto the family, a process of familialisation (Edwards \& Alldred, 2000). This is also a part of the new process of individualisation in western societies where individuals are given greater responsibility for their life choices, including education (Blackmore \& Hutchison, 2010).

The vertical and horizontal frameworks can therefore be used to understand problems and advantages of different levels of parental relationship. This might be relevant to study more extensive as there seems to be different trends in the ECEC curriculums in different countries.

\section{Parental Relationship in ECEC Curriculum}

Not all countries have national curricula for the ECEC, but -there is a trend with more regulation worldwide of the ECEC goals (Wood \& Hedges, 2016). The parental relationship seems to be understood a bit different in curriculum from different countries and as example the ECEC curriculum of Australia and Sweden can be compared.

From Australia the policy of "Belonging, Being \& Becoming - The Early Years Learning Framework for Australia" is used (DET, 2009/2019).

"In genuine partnerships, families and early childhood educators:

- $\quad$ value each other's knowledge of each child

- value each other's contributions to and roles in each child's life

- trust each other

- $\quad$ communicate freely and respectfully with each other

- $\quad$ share insights and perspectives about each child

- $\quad$ engage in shared decision-making" (DET, 2009/2019, 13)

From Sweden the national curriculum is used from 2018 (Lpfö, 18).

\section{"The work team should}

- assume responsibility for developing a trusting relationship between the preschool and the home,

- be clear about the goals and content of the education in order to create the conditions for the opportunities of children and guardians to have an influence,

- maintain an ongoing dialogue with children's guardians about the child's well-being, development and learning, and hold development dialogues, and

- keep informed about children's personal circumstances with respect for children's integrity." (Lpfö18, 18)

The Australian ECE curricula, seems to have a horizontal framework, using the concept of genuine partnership to parents and shared decision-taking. The Swedish curricula can be understood as vertical framed using the concept of trusting relationship and keeping parents informed.

\section{Materials and Methods}

This study was conducted in the form of a systematic review of international research articles concerning relationships to parents in ECEC. The reason for this choice was that high quality research can give an insight to an educational area, how it is described and understood.

The empirical material consisted of articles in English in international scientific journals. The articles were found in the Academic Search Elite database, (a multidisciplinary rich resource spanning a broad stretch of academic subjects), using different combinations of the search terms "parents/parental", “involvement", "engagement" and "partnership". A total of 39 articles were found. After an exclusion of articles that lacked aspects of ECEC services, 22 articles remained. These 22 articles are represented in eight journal and studies done in 16 countries, the earliest from 2001 and the most recent from 2018. The represented countries were Australia, Belgium, Canada, China, Denmark, Finland, Germany, Greece, Ireland, Netherlands, New Zealand, Nigeria, Spain, Sweden, United Kingdom and United States.

As Epstein's model consists of many levels and some exhibit similarities, this study considered it more functional to reduce these five types to three levels instead when studying parental relationships in ECEC. The first level refers to a basic parental involvement, where parents pay visits to the services, communicate with and are interested in their programmes (Alasuutari, 2010). The second level, parental engagement, refers to a deeper and more personal parental relationship where parents are more active and participate in the ECEC activities at home or in the services (Goodall \& Montgomery, 2014). The third level is parental partnership, where parents and professionals are more like equal partners and where parents exert a clear influence on ECEC activities (Epstein, 2018; Foot et al., 2002; Keyes, 2002). 
Categorizing into the three levels was carried out according to their use of the different concepts of involved, engaged or partnership in the relations with parents in the ECEC, in kind of content analyze inspired by Krippendorf (1980).

In order to obtain a picture of how the parental relationship is understood in the articles, a qualitative analysis was conducted to identify advantages and problems connected with these relationships. In this analysis, there is a kind of mapping of ideas (Hart, 2018) or thematic analysis (Bryman, 2012; Strauss \& Corbin, 1996). The articles were studied all together in order to obtain an overall understanding, which also seemed relevant as most articles included some aspect from several levels. Typical citations from the articles are presented for all categories found.

One methodological problem was to identify all the relevant articles as the number found was quite limited. Another problem in this study was that it was not always clear how to categorise the articles into the three levels as many articles used concepts from different levels and also focused on different level in different parts of the articles.

\section{Results}

\section{Involved, Engaged or Partnership Relationship}

The 22 articles studied have been categorised broadly into the three parental relationships (Table 1). Eight of the articles to some extent use concepts from all three levels, eight articles use concepts from two levels and three articles use concepts from one level.

Table 1. Three levels of parental relationship in ECEC found in the studied articles $(\mathrm{n}=22)$.

\begin{tabular}{|c|c|c|}
\hline Level & Authors (see references for details) & Count \\
\hline Partnership & $\begin{array}{c}\text { Alasuutari (2009; 2010) } \\
\text { Chan \& Ritchie (2016) } \\
\text { Cottle \& Alexander (2014) } \\
\text { Einarsdottir \& Jónsdóttir (2017) } \\
\text { Foot et al. (2002) } \\
\text { Hujala et al. (2009) } \\
\text { Markström (2009) } \\
\text { Nichols \& Jurvansuu (2008) } \\
\text { Tayler (2006) } \\
\end{array}$ & 10 \\
\hline Involvement & $\begin{array}{c}\text { Dalli (2008) } \\
\text { Hakyemez-Paul et al. (2018) } \\
\text { Hughes \& MacNaughton (2000; 2001) } \\
\text { Janssen \& Vandenbroeck, 2018) } \\
\text { Knopf \& Swick (2007) } \\
\text { Markström (2011) } \\
\text { Patel \& Corter (2013) }\end{array}$ & 8 \\
\hline Engagement & $\begin{array}{c}\text { Chen et al. (2012) } \\
\text { Paz-Albo Prieto (2018a; 2018b) } \\
\text { Rentzou \& Ekine (2017) }\end{array}$ & 4 \\
\hline
\end{tabular}

The parental relationship as partnership, found in ten articles, focuses on empowerment, equal power and shared decision-making.

...parent-teacher partnership involves a trusting, respectful relationship, two-way-communication, collaboration, empowerment, equal power and shared decision-making, rather than parents being 'advised' about how to rear their children or expected to conform to the teacher's expectations. (Chan \& Ritchie, 2016, 292)

The parental relationship as involvement, found in seven articles, parents are involved in the ECEC service but the teachers have more responsibility.

... although parents, educators and principals together establish collaboration between the educational institution and home, educators bear slightly greater responsibility in this area. (Hakyemez-Paul et al. 2018, 267)

The parental relationship as engagement was found in four articles and here the focus is on communication between parents and the ECEC service.

In fact, positive and constructive communication with parents is seen as an asset to build effective family-school partnerships. (Paz-Albo Prieto, 2018a, 619)

Even if the articles can be categorised into the three levels, many articles also to some extent use expressions from other levels. At the partnership level, eight articles show indications of parental involvement, and four articles show indications of parental engagement. In the involvement level, five articles also show aspects of parental partnership and three articles show aspects of parental engagement. The parental engagement level shows aspects of parental partnership in three articles, and aspects of parental involvement in three other articles.

\section{Advantages of Parental Relationships}

The 22 articles studied four general advantages gained from parental relationship appear in (Table 2). Here all articles are studied together to get an overall picture.

Table 2. Advantages of parental relationship in ECEC found in the studied articles $(\mathrm{n}=22)$

\begin{tabular}{|c|c|c|}
\hline Advantage & Authors (see references for details) & Count \\
\hline $\begin{array}{c}\text { Quality-indicator } \\
\text { of the ECEC } \\
\text { service }\end{array}$ & $\begin{array}{c}\text { Cottle \& Alexander (2014) } \\
\text { Foot et al. (2002) } \\
\text { Hujala et al. (2009) }\end{array}$ & 7 \\
\hline $\begin{array}{c}\text { Janssen \& Vandenbroeck (2018) } \\
\text { Knopf \& Swick, (2007) } \\
\text { Paz-Albo Prieto (2018a) } \\
\text { Tayler (2006) }\end{array}$ & Empowerment \\
of parents & $\begin{array}{c}\text { Chan \& Ritchie (2016) } \\
\text { Cottle \& Alexander (2014) } \\
\text { Hujala et al. (2009) } \\
\text { Foot et al. (2002) }\end{array}$ & 6 \\
\hline $\begin{array}{c}\text { Impact on } \\
\text { children's } \\
\text { achievement in } \\
\text { schools }\end{array}$ & $\begin{array}{c}\text { Knopf \& Swick (2007) } \\
\text { Hujala et al. (2009) }\end{array}$ & 3 \\
\hline $\begin{array}{c}\text { Flexible } \\
\text { relationship }\end{array}$ & Patel \& Corter (2013) & 2 \\
\hline
\end{tabular}

The first advantage from parental relationships found in seven articles is described in general terms as an important 
part of the ECEC services as it deals with young children of early years and is a kind of indicator of high quality.

Findings suggest that early childhood tutors have a positive perspective of parental involvement and play a key role in supporting active school involvement of parents that enhance the quality of ECEC programmes. (Paz-Albo Prieto, 2018a, 613)

The second general advantage that research highlights is that the parental relationship can empower parents. This is identified in six articles.

By focusing on empowering parents and families and on collaboration that embraces diversity as resource (Souto-Manning and Swick 2006), new windows of opportunities may open up. (Einarsdottir \& Jónsdóttir, 2017, 13)

The third advantage found in three articles in this review is that parental relationships in ECEC can exert impact on children's future achievement in schools.

There is now strong research that demonstrates that involvement of parents in ECEC and early intervention services has positive effects on children's achievements (McCuthen 2002; Sand \& Skoug 2002). (Hujala et al. 2009, 60)

The fourth advantage found in two articles in this review is that parental relationship for ECEC services can be carried out in several ways and show a kind of flexibility, especially compared with schools for older children.

In comparison with schools, the practices and models of partnership described in Children's Centre and nurseries appeared to be more flexible. (Cottle \& Alexander, 2014, 650)

\section{Problems of Parental Relationships}

The 22 articles studied three general problems with parental relationship appear in (Table 3).

Here also all articles are studied together to get an overall picture.

Table 3. Problems with the parental relationship found in the studied articles $(n=22)$.

\begin{tabular}{|c|c|c|}
\hline Problem & Authors (see references for details) & Count \\
\hline $\begin{array}{c}\text { Parents and } \\
\text { teachers different } \\
\text { roles }\end{array}$ & $\begin{array}{c}\text { Alasuutari, (2010) } \\
\text { Chan \& Ritchie, (2016) } \\
\text { Hakyemez- Paul et al. (2018) } \\
\text { Hughes \& MacNaugthon (2000) } \\
\text { Hujala et al. (2009) }\end{array}$ & 5 \\
\hline $\begin{array}{c}\text { Chen et al. (2012) } \\
\text { Cottle \& Alexander (2014) }\end{array}$ & 3 \\
\hline $\begin{array}{c}\text { Complex } \\
\text { relationship }\end{array}$ & $\begin{array}{c}\text { Cottle \& Alexander (2014) } \\
\text { Markström (2009) }\end{array}$ & 2 \\
\hline
\end{tabular}

The first problem highlights the different roles of parents and teachers and included both aspects of parents not willing to engage with ECEC and teachers not wanting parents to exert any influence in the ECEC.

However, we cannot assume that that all parents who wish to become involved in their children's care and education are equally able to do so. (Hughes \& MacNaugthon, 2000, 256)

ECEC staff is described as experts of child development and education, parents on the other hand are not thought to the have the same level of expertise. (Alasuutari, 2010, 153)

The second problem is that the demands of the parental relationship can be more difficult to achieve for all parents and that parents from minority cultures and working-class parents may be discriminated against.

Firstly, the current systems advantage middle class parents. Secondly, that targeted intervention approaches that may be insensitive to family culture (Feiler et al. 2006) which again has connotations for both working class parents and ethnic minorities. (Cottle \& Alexander, 2014, 655)

The third and final problem found in the research is that the parental relationship is quite complex, and that this phenomena is simplified in working of the policies.

... and the tensions inherent in policy discourses which tend to oversimplify highly complex relationships (Blackmore and Hutchison 2010). (Cottle \& Alexander, 2014, 638)

The present study helps to explore some of the complexities: parent-teachers conferences are processes which extend through time and space, i.e. they do not only consist of the realisation of the face-to-face interaction in single encounters, but also of a range of preparatory work. (Markström, 2009, 130)

\section{Discussion}

One conclusion of this review is that parental relationship in ECEC can be divided broadly in three levels: parental involvement, engagement and partnership. The fact that ten articles of 22 articles focus on parental partnership and that eight other articles use this concept to a certain extent to indicate a dominance of this level in the area of parental relationships ( $82 \%$ of the articles use the concept). There is also an indication that levels overlap to a certain extent, as 16 articles use some concepts from two or three levels and three articles use concepts from one level.

The second conclusion of this review is that four general advantages of parental relationships are identified in the research: as quality-indicator, as empowerment of parents, as impact on student future achievement in schools and as 
the flexibility of the relationship. The third and final conclusion is that three general problems of parental relationships have been identified in the research: the different roles of parents and teachers, discrimination and the complexity of these relationships.

One interesting discussion is why the level of parental partnership is so dominant. This level with its focus on equal partnership between parents and teachers can be understood as belonging to the horizontal framework (Aronsson \& Evaldsson, 1993). This is in line with the findings of Alasuutari (2010), and may be of importance for democratic professionalism in ECEC (Einarsdottir \& Jónsdóttir, 2017). This result is also supported by the empowerment advantage of the parental relationship found in this study. This is in line with ideas of democratic education in ECEC in respecting diversity, recognising multiple perspectives and welcoming curiosity and uncertainty (Dahlberg \& Moss, 2005). The horizontal framework with its close relationship with parents also has the benefit of providing a less restrictive and more relational picture of the child than in the vertical framework (Alasuutari, 2010). Even if the horizontal framework does show some visual domination by the use of the concepts from this level, it may be doubted how well it can be realised as some of the problems in the parental relationship seem to have connections with this level.

One problem found in this review as concerns parental relationships that interferes with the horizontal framework is the possibility of maintaining an equal relationship between parents and the ECEC service in that parents and teacher have different roles. It is quite obvious, and also strengthened by more regulated ECEC policy and integration of ECEC in educational systems (Bennet, 2005; Bennet \& Kaga, 2010), that teachers with their professional education, attendance and responsibility for the ECEC service inhabit a different reality and hold more power than parents in this context. However, parents do have important knowledge about their young children and in some aspects there is a kind of equality between parents and the ECEC service as the parents in legal terms, have to a certain extent more power than the teachers. For example, if the parents are not satisfied with the service, they can choose other services or alternatives for their childcare. The parents are also often referred to as the children's first educator indicating the educational role of the parents (Cottle \& Alexander, 2014).

Another problem identified that to a certain extent interferes with the horizontal framework is the discrimination factor. How is it possible to see parents as equal partners when the teachers often favour middle-class parents and possess less knowledge of and understanding of families from different ethnicity or social grouping. Often the curriculum, its implementation in the services and the teacher background are dominated by middle-class belonging thinking. However, on the other hand in the thinking of the horizontal framework, the close relationship to parents brings opportunities to open up the minds of the teachers regarding differences. It might even be the vertical framework thinking with teachers as experts that might be the problem causing the discrimination. Teachers may also, as those more responsible for the service, be aware of this problem and be attempting to deal with it. The problem might not be clear related to one of the frameworks at all and merely indicate that the frameworks are overlapping and the problems are actually more general and complex.

The identification of the problem concerning the complexity of the parental relationship in ECEC is extremely interesting. This gives a broader, nuanced, understanding of this relationship. Cottle and Alexander (2014) highlight that policy discourses oversimplify the highly complex parental relationship. This complexity might be the case with many aspects of the implementation of policy issues in ECEC service, but some issues might be more problematic. One interpretation of the dominant use of the level of parental partnership in the research may be that it is also the type of discourse about ECEC that is expressed in policies. As a sort of consequence of the individualisation of our societies, the parents are regarded as important factor when writing policies (Blackmore \& Hutchinson, 2010). This importance of the parental relationship is not new, even in the early kindergarten of Froebel this relationship was important (Pramling Samuelsson et al., 2006). In today's society the mention of parents in the policies as partners might attract parents in their choice of ECEC service as it indicates a clear focus and respect for parents. This might attract more middle-class families who enjoy the opportunity to choose different ECEC services. As the complexity in this reasoning has to do with the realisation of policies and is a type of hierarchical way of thinking and seems to be connected to the vertical frame.

The advantage of flexibility in the parental relationship in ECEC that was identified, especially as compared with schools, can be used to reduce any problems in the parental relationship. This flexibility may be due to the fact that the parental contacts are more extensive in the ECEC service as compared to schools. Contacts are often both formal and informal in different ways. However, perhaps these contacts can also be quite traditional in many aspects. If the service wants to reduce the problems of discrimination, alternative ways with more sensitive and open-minded approaches to parents of different cultures and traditions could be a solution (MacNaugthon \& Hughes, 2011; Souto-Manning \& Swick, 2006). Here the flexibility of the parental relationship could be elaborated even more. By asking and listening to all the parents concerning how they think the relationship could be realised, new ideas on how to get more parents engaged in the service could be identified. If the flexibility of the relationship is utilised in these kinds of alternative manners in close cooperation with parents, this could be interpreted as being linked to the horizontal frame. 
One interesting aspect found in this study is that of parental relationship as indicator of high quality of the ECEC service and its impact on children's future achievements in school. These aspects are a little general and diffuse in some senses and they are not clear connected with either of the two frameworks. However, they do indicate some very important aspects of the parental relationship. As an indicator of quality, it is essential to mention the parental relationship in ECEC policy and also it must be taken seriously in the provision of the service. Also, the fact that the parental relationship impacts on the children's future achievement in schools highlights the importance of the relationship and also how essential it can be to maintain functional relationships with all parents. It is maybe not possible to achieve with all parents, but teachers working for democratic professionalism in ECEC should have this as a clear-defined ambition (Einarsdottir \& Jónsdóttir, 2017).

The final conclusion is that a more realistic way to think of a balance between vertically and horizontally-framed parental relationship in ECEC services. The parental partnership has its advantages but it is not realistic to see parents and teachers as full equal partners. It is maybe more realistic to use concepts such as "a kind of partnership with parents" or "collaboration with parents". In today's democratic societies, "partnership" often is understood as partners with equal roles. It may also be more realistic to use of the vertical framework as "involvement" and "engagement". It may be of great importance to highlight the parental relationship in ECEC service in all countries, whatever it is called. This review did reveal that teachers in some countries are sceptical about the voice of the parents (Hujala, et al., 2009), and also some countries lack any mention of the parental relationship in the ECEC policy (Renzou \& Ekine, 2017). However, this is quite weak indication that the introduction of more academic ECEC curriculum has a negative effect on the parental relationship. Consequently, there is a need for more research in the area of parental relationship in ECEC.

\section{Disclosure Statement}

No potential conflict of interest was reported by the author.

\section{REFERENCES}

[1] Alasuutari, M. (2009). What is so funny about children? Laughter in parent-practitioner interaction. International Journal of Early Years Education, 17(2), 105-118.

[2] Alasuutari, M. (2010). Striving at partnership: Parent-practitioner relationships in Finnish early educators' talk. Early Childhood Education Research Journal, 18(2),
149-61.

[3] Alasuutari, M., \& Markström, A.-M. (2011). The making of the ordinary child in preschool. Scandinavian Journal Educational Research, 55(5), 517-535.

[4] Arnold, D.H., Zeljo, A., \& Doctoroff, G.L. (2008). Parent involvement in preschool: Predictors and the relation of involvement to preliteracy development. School Psychology Review, 37(1), 74-90.

[5] Aronsson, K., \& Evaldsson, A.-C. (1993). Pedagogic discourse and interaction orders: Sharing time and control. In N. Coupland \& J.F. Nussbaum (ed), Discourse and lifespan identity (103-31). Newbury Park, California: Sage.

[6] Bennet, J. (2005). Curriculum issues in national policy-making. European Early Childhood Education Research Journal, 13(2), 5-23.

[7] Bennet, J., \& Kaga, Y. (2010). The integration of early childhood system within education. International Journal of Child Care and Education Policy, 4(1), 35-43.

[8] Bernstein, B. (1990). The structuring of a pedagogic discourse. London: Routledge

[9] Blackmore, J., \& Hutchison, K. (2010). Ambivalent relations: the 'tricky footwork' of parental involvement in school communities. International Journal of Inclusive Education, 14(5), 499-515.

[10] Bryman, A. (2012). Social Research Methods. Oxford, Oxford University Press

[11] Castelli, S., \& Pepe, A. (2008). School-parent relationship: A bibliometric study on 40 years of scientific publications. International Journal of Parents in Education, 2(2), 1-12.

[12] Chan, A., \& Rithie, J. (2016). Parents, participation, partnership: Problematising New Zealand early childhood education. Contemporary Issues in Early Childhood, 17(3), 289-303.

[13] Chen, J., Pisani, L., White, S., \& Soroui, J. (2012). Parental engagement in early childhood education at home. Reading Psychology, 33, 497-524.

[14] Chu, S.-Y. (2018). Perspectives from both sides of parental-professional partnership: A preliminary study on Taiwan's early childhood special education services. International Journal of Disability, Development and Education, 65(4), 355-72.

[15] Cottle, M. \& Alexander, E. (2014). Parents partnership and 'quality' early years services: Practitioners' perspectives. European Early Childhood Education Research Journal, 22(5), 637-659.

[16] Cox, D.D. (2005). Evidence-based interventions using home-school collaboration. School Psychology Quarterly, 20(4), 473-97.

[17] Dahlberg, G., \& Moss, P. (2005). Ethics and Politics in Early Childhood Early Childhood Education. London: Falmer Press.

[18] Dalli, C. (2008). Pedagogy, knowledge and collaboration: Towards a ground-up perspective on professionalism. European Early Childhood Education Research Journal, 16(2), 171-85 
[19] Daniel, G. (2015). Patterns of parent involvement: A longitudinal analysis of family-school partnerships in the early years of school in Australia. Australasian Journal of Early Childhood, 40(1), 119-128.

[20] Department of Education and Training (DET). (2009/2019). Belonging, Being \& Becoming: The Early Years Learning Framework for Australia. Canberra, ACT: Commonwealth of Australia. Retrieved 15 April 2020 from https://docs.education.gov.au/system/files/doc/other/belongi ng_being_and_becoming_the_early_years_learning_frame work_for_australia_0.pdf

[21] Donzelot, J. (1997). The policing of families. Baltimore, Md.: John Hopkins University Press.

[22] Dunlap, G., \& Fox, L. (2007). Parent-professional partnerships: A valuable context for addressing challenging behaviours. International Journal of Disabilities, Development and Education, 54(3), 273-285.

[23] Dunst, C.J., \& Dempsey, I. (2007). Family-professional partnerships and parenting competence, confidence and enjoyment. International Journal of Disability, Development and Education, 54(3), 305-18.

[24] Edwards, A., \& Alldred, P. (2000). A typology of parental involvement in education centring on children and young people: Negotiating familialisation, institutionalisation and individualisation. British Journal of Sociology of Education, 21(3), 435-55.

[25] Einarsdottir, J., \& Jónsdóttir, A.H. (2017). Parent-preschool partnership: Many levels of power. Early Years, 39(2), 175-189.

[26] Epstein, J.L. (1990). School and family connections: Theory, research, and implications for integrating sociologies of education and family. Marriage and Family Review, 15, 99-126.

[27] Epstein J.L. (2018). School, Family and Community Partnerships: Preparing Educators and Improving Schools. Student Economy Edition. $2^{\text {nd }}$ ed. Boulder, CO: Westview.

[28] Foot, H., Howe, C., Cheyne, B., Terras, M., \& Rattray, C. (2002). Parental participation and partnership in pre-school provision. International Journal of Early Years Education, 10(1), 5-19.

[29] Franklin, B.M., Bloch, M.N., \& Popkewitz, T.S. (2004). (ed.). Educational Partnerships and the State: The paradox of governing Schools, Children and Families. New York: Palgrave Macmillan.

[30] Galindo, C. \& Sheldon, S.B. (2012). School and home connections and children's kindergarten achievement gains: The mediating role of family involvement. Early Childhood Research Quarterly, 27(1), 90-103.

[31] Goodall, J., \& Montgomery, C. (2014). Parental involvement to parental engagement: A continuum. Educational Review, 66(4), 399-410.

[32] Hakyemez-Paul, S., Pihlaja, P., \& Silvennoinen, H. (2018). Parental involvement in Finnish day care: What do early childhood educators say? European Early Childhood Education Research Journal, 26(2), 258-273.

[33] Hart, C. (2018). Doing a literature review: Releasing the research imagination. 2 nd ed. Thousands Oaks, CA: Sage.
[34] Hilado, A.V., Kallemeyn, L, \& Phillips, L. (2013). Examining understandings of parental involvement in early childhood programs. Early Childhood Research \& Practice, 15(2).

[35] Hornby, G., \& Lafaele, R. (2011). Barriers to parental involvement in education: An explanatory model. Educational review, 63(1), 37-52.

[36] Hughes, P., \& MacNaughton, G. (2000). Consensus, Dissensus, or Community: The politics of parent involvement in Early Childhood. Contemporary Issues in Early Childhood, 1(3), 241-58.

[37] Hughes, P., \& MacNaughton, G. (2001). Building equitable staff parent communication in early childhood settings: An Australian study. Early Childhood Research \& Practice, $3(2)$.

[38] Hujala, E., Turja, L., Filomena Gaspar, M., Veisson, M., \& Waniganayake, M. (2009). Perspectives of early childhood partnerships in five European countries. European Early Childhood Education Research Journal, 17(1), 57-76.

[39] Ivarsson Jansson, E. (2001). Relationen hem - förskola: Intentioner och uppfattningar om förskolans uppgift att vara ett komplement till hemmet 1990-1995 [Relational Family Preschool: Intentions with and conceptions of the Preeschool task to be "a complement to the home"] (Doctoral dissertation). Umeå: Umeå University, Sweden.

[40] Janssen, J., \& Vandenbroeck, M. (2018). (De) constructing parental involvement in early childhood curricula frameworks. European Early Childhood Education Research Journal, 26(6), 813-832.

[41] Jeynes, W.H. (2018). A practical model for school leaders to encourage parental involvement and parental engagement. School Leadership \& Management, 38(2), 147-163.

[42] Jinnah, A.H., \& Walters, L.H. (2008). Including parents in evaluation of child development program: Relevance of parental involvement. Early Childhood Research \& Practice, $10(1)$

[43] Keen, D. (2007). Parents, families, and partnerships: Issues and considerations. International Journal of Disability, Development and Education, 54(3), 339-49.

[44] Keyes, C.R. (2002). A way of thinking about parent/teacher partnerships for teachers. International Journal of Early Years, 10(3), 177-191.

[45] Knopf, H.T., \& Swick, K.J. (2007). How parents feel about their child's teacher/school: Implications for early childhood professionals. Early Childhood Education Journal, 34(4), 291-296.

[46] Krippendorff, K. (1980). Content Analysis. Beverly Hills, London: SAGE.

[47] Leiminer, M., \& Baker, C. (2000). A child's say. Talk at the preshool: Conversation analytic research in early childhood settings. Contemporary Issues in Early Childhood, 1(2), $135-152$.

[48] Lpfö 18 (2018). Läroplan för förskolan [Curriculum for preschool]. Stockholm, Sweden: Ministry of Education and Science.

[49] Löfdahl, A. (2014). Teacher-parent relations and 
professional strategies: A case study on documentation and talk about documentation in a Swedish preschool. Australasian Journal of Early Childhood, 39(3), 103-110.

[50] MacNaughton, G., \& Hughes, P. (2011). Parents and Professionals in Early Childhood Settings. New York: Routledge.

[51] Markström, A.-M. (2009). The parent-teacher conference in the Swedish preshool: A study of an ongoing process as a 'pocket of local orders'. Contemporary Issues in Early Childhood, 10(2), 122-132.

[52] Markström, A.-M. (2011). To involve parents in the assessment of the child in parent-teacher conferences: A case study. Early Childhood Education Journal, 38, 465-474.

[53] McWilliam, R.A., Tocci, L., \& Harbin, G.L. (1998). Family-centered services: service providers' discourse and behaviour. Topics in Early Childhood Special Education, 18(4), 206-22.

[54] Mercedes Nalls, A., Mullis, R.L., Cornille, T.A., Mullis, A.K., \& Jeter, N. (2010). How can we reach reluctant parents in childcare programmes? Early Child Development and Care, 180(8), 1053-64.

[55] Moss, P. (2007). Bringing politics into the nursery: Early Childhood Education as a democratic practice. European Early Childhood Education Research Journal 15(1), 5-20.

[56] Nichols, S., \& Jurvansuu, S. (2008). Partnership in integrated early childhood service: An analysis of policy framings in education and human services. Contemporary Issues in Early Childhood, 9(2), 117-130.

[57] Patel, S., \& Corter, C.M. (2013). Building capacity for parent involvement through school-based preschool services. Early Child Development and Care, 183(7), 981-1004.

[58] Paz-Albo Prieto, J. (2018a). Enhancing the quality of early childhood education and care: ECEC tutors' perspectives of family engagement in Spain. Early Child Development and Care, 188(5), 613-623.

[59] Paz-Albo Prieto, J. (2018b). The influence of simulations on family engagement: Prospective early childhood educators' perceptions. Early Child Development and Care, 188(2),
102-108.

[60] Pomerantz, E. M., Moorman, E.A., \& Litwack, S.D. (2007) The how, whom and why of parents' involvement in children's academic lives: More is not always better. Review of Educational Research, 77(3), 373-410.

[61] Pramling Samuelsson, I., Sheridan, S., \& Williams, P. (2006). Five preschool curricula: A comparative perspective. International Journal of Early Childhood, 38(1), 11-29.

[62] Rentzou. K., \& Ekine, A. (2017). Parental engagement strategies in Greek and Nigerian preschool settings: Cross-country comparison. International Journal of Early Years Education, 25(1), 30-50.

[63] Rimm-Kaufman, S.E., \& Pianta, R.C. (2001). An ecological perspective on the transition to kindergarten: A theoretical framework to guide empirical research. Journal of Applied Development Psychology 21, 179-198.

[64] Rouse, E., \& O'Brien, D. (2017). Mutuality and reciprocity in parent-teacher relationships: Understanding the nature of partnerships in early childhood education and care provision. Australasian Journal of Early Childhood, 42(2). 45-52.

[65] Souto-Manning, M., \& Swick, K.J. (2006). Teachers beliefs about parent and family involvement: Rethinking our family involvement paradigm. Early Childhood Education Journal, 34(2), 187-193.

[66] Strauss, A., \& Corbin, J.M. (1996). Basics of Qualitative Research Techniques and Procedures for Developing Grounded Theory. Newbury Park, CA: Sage.

[67] Summers, J.A., Marquis, J., Mannan, H., Turnbull, A.P., Fleming, K., Poston, D.J., Wang, M., \& Kupzuk, K. (2007). Relationship of perceived adequacy of services, family-professional partnerships, and family quality of life in early childhood service programmes. International Journal of Disability, Development and Education, 54(3), 319-38.

[68] Tayler, C. (2006). Challenging partnerships in Australian early childhood education. Early Years, 26(3), 249-265.

[69] Wood, E., \& Hedges, H. (2016). Curriculum in early childhood education: Critical questions about content, coherence, and control. Curriculum Journal, 27(3), 387-405. 